\title{
los 5
}

Volume 2 (1) (2019): 21-26

\section{The Indonesian Journal of Social Studies}

\author{
Available at https://journal.unesa.ac.id/index.php/jpips/index
}

\section{Development of History Textbooks using Model MORE (Model, Observe, Reflect, Explain)}

\author{
Sutoyo Budiharto 1) *, Nasution 2), Ismet Basuki ${ }^{3)}$ \\ 1) MA Negeri 1, Pontianak, Indonesia \\ 2) Fakultas Ilmu Sosial dan Hukum, Universitas Negeri Surabaya, Indonesia \\ 3) Fakultas Ilmu Sosial dan Hukum, Universitas Negeri Surabaya, Indonesia
}

\begin{abstract}
Abstrak
Penelitian pengembangan bertujuan untuk menghasilkan buku teks sejarah yang efektif untuk digunakan dalam pembelajaran sejarah. Buku teks sejarah yang dikembangkan menggunakan model pembelajaran MORE (model, observe, reflect, explain). Jenis penelitian adalah pengembangan dengan mengadaptasi model pengembangan 4-D Thiagarajan. Teknik pengumpulan data dalam penelitian ini menggunakan lembar validasi, angket, observasi, dan tes. Data yang diperoleh dari hasil penelitian dianalisis dengan uji statistik dan deskriptif. Tes empiris dalam penelitian ini menggunakan metode pra-eksperimen dengan desain satu kelompok pretest posttest. Subjek penelitian ini adalah siswa kelas X IPS 2 di MAN 1 Pontianak. Hasil penelitian, 1) Kualitas model buku teks sejarah MORE memiliki kualitas yang baik berdasarkan evaluasi validator. 2) Buku teks sejarah menggunakan model MORE memiliki pengaruh signifikan pada pembelajaran sejarah.

Kata Kunci: buku teks, pembelajaran sejarah, model MORE
\end{abstract}

\begin{abstract}
Development research aims to produce effective historical textbooks for use in historical learning. Historical textbooks developed using the learning model MORE (model, observe, reflect, explain). The type of research is development by adapting the Thiagarajan 4-D development model. Data collection techniques in this study used a sheet of validation, questionnaire, observation, and test. Data obtained from the results of the study were analyzed by statistical and descriptive tests. The empirical test in this study used the method pre-experimental with design one group pretest posttest. The subjects of this study were students of class XIPS 2 at MAN 1 Pontianak. Research results, 1) The quality of the history textbook model MORE has good quality based on the evaluation of the validator. 2) Historical textbooks using the model MORE can have a significant influence on historical learning.

Keywords: textbook, history learning, model MORE
\end{abstract}

How to Cite: Budiharto, S. Nasution, N. \& Basuki, I. (2019). Development of History Textbooks using Model MORE (Model, Observe, Reflect, Explain). The Indonesian Journal of Social Studies, Vol 2(1): 21-26

${ }^{*}$ Corresponding author:

E-mail: sutoyobudiharto@yahoo.com
e-ISSN 2615-5966 (Online)

This is an open access article under the CC-BY-SA license 


\section{INTRODUCTION}

The main objectives in education are to produce high-quality learning outcomes for graduates (Trigwell \& Poster, 1991). Changes in individuals can be seen through learning outcomes obtained by students in learning (Maher, 2004). Most researchers consider that the results of knowledge learning are important to know the level of students' ability to understand the material in learning (Shephard, 2008).

One of the learning outcomes that is a major concern is cognitive learning outcomes. Cognitive learning outcomes are obtained based on proven knowledge and skills, what students know in advance and what they can do that they previously could not do (Richard Frye, 1999). Knowledge assessment aims to measure students' cognitive abilities (Kosasih, 2016). Student learning outcomes can be better (aspects of knowledge) by involving students in learning activities (Michel et al., 2009). One of the learning models that guides students to gain learning experience is the model MORE. Learning the model MORE encourages students to actively develop their own knowledge in answering scientific questions (Tien et al., 2007). Learning the model MORE has four stages, namely the model, observe, reflect and explain (Carillo et al., 2005).

In the stage model, at this stage students are asked to describe their current understanding of the system to be investigated. At the time of forming understanding, students can use words and images to represent their ideas. The truth in the initial understanding is not prioritized. Stage Observe, students conduct experiments to investigate the topics presented. Atstage reflect, students are encouraged to reflect both during and after the experiment. At this stage, the teacher also asks questions to encourage students to reflect deeply on learning. In the stage explaining, students hold discussions on their observations and reflections in small groups. Students make improvements to the model they make. Students are asked to explain based on the observations they have received.

Learning models MORE will be better if there are teaching materials. Teaching materials are used to improve student reflections for the better (Carrilo et al., 2005). Teaching materials are all forms of material used by teachers and students in carrying out teaching and learning activities in the classroom (Daryanto \& Dwicahyono, 2014). Teaching materials have a very important role in learning. One of the main sources used in learning is textbooks (Ahmadi \& Amri, 2014). Students' textbooks are very important for teachers and students to convey the methods of learning in learning (Bruhn \& Hasselbring, 2013).

Students use textbooks to understand the material as a whole. Student textbooks are also used by students to prepare for the exam. Therefore, each student textbook must be designed with good quality and in accordance with the student's perspective in understanding the contents of the book (Gurung \& Landrum, 2012). A good textbook is a textbook that has a clear learning framework for students to understand (Howson, 2013). A good textbook has a strong relationship in influencing learning outcomes and student learning achievement in learning (Yang \& Sianturi, 2017).

Seeing this, there are still many textbooks that have not met good qualifications to improve student learning outcomes and achievements. Commercially produced student textbooks tend to offer small scale pragmatic learning (Nguyen, 2011). Commercially produced student textbooks also sometimes have different content and material from the curriculum issued by the government (Faas \& Ross 2012). Based on previous research regarding the availability of student textbooks, this study focuses on developing historical textbooks using the model MORE (model, observe, reflect, explain). The formulation of the problem in this study, 1) What is the quality of history textbooks using the model MORE (model, observe, reflect, explain) ?.2) How is the student learning outcomes after using history textbooks with the model MORE (model, observe, reflect, explain) ?. 
3) What is the readability of teaching books by using the model MORE (model, observe, reflect, explain) ?. Based on the formulation of the problem, the purpose of this study is Beirkut, 1) Describe the quality of history textbooks using the model MORE (model, observe, reflect, explain). 2) Describe student learning outcomes after using history textbooks with model MORE (model, observe, reflect, explain). 3) Describe the readability of teaching books by using the model MORE (model, observe, reflect, explain)?

\section{METHOD}

This research uses the design of research \& development (R \& D). The development model used by the researcher was the Thiagarajan 4-D model which consisted of define, design, develop, and disseminate (Thiagarajan, 1974). In this study, researchers only used three stages, namely define, design, and develop. The study was conducted in MAN 1 Pontianak, with 38 subjects of IPS 2 class as many as 38 students. Data collection techniques in this study used a sheet of validation, questionnaire, observation, and test. The validation sheet is used to determine the quality of the history textbook developed. Questionnaire is used to determine the legibility of history textbooks. Observations were used to collect preliminary data on the condition of student textbooks in MAN 1 Pontianak by conducting direct surveys. The test is used to find out the learning outcomes (student knowledge competencies) after using textbooks. Data obtained from the results of the study were analyzed by statistical and descriptive tests. The empirical test in this study used themethod pre-experimental withdesign one group pretest posttest. The design of this study uses one research class by giving a pre test first, then treatment using themodel history textbook MORE and ending by the post test (Chreswell, 2016, p. 230). The statistical test used to determine the effect of student learning outcomes using themodel textbook MORE is the paried sample t test.

\section{RESULT AND DISCUSSION}

At thestage define, the researcher conducted a preliminary study by conducting field observations first at MAN 1 Pontianak. The observations that were conducted focused on the availability of student textbooks in the environment of MAN 1 Pontianak. Based on the results of observations, it is known that history teachers at MAN 1 only use student work sheets during the teaching and learning process. During the teaching and learning activities, the teacher only used a student work sheet to deliver the subject matter. History teachers also argue that studet work sheets are sufficient in shaping students' knowledge in historical subjects.

In thephase design, researchers developed a history textbook by combining thelearning model MORE in textbooks. At thestage design, researchers designed textbooks based on the Republic of Indonesia Minister of Education and Culture Regulation Number 8 of 2016. The regulation regulates books used by educational units. Textbooks must be in line with the values of Pancasila, the 1945 Constitution and positive norms that apply in society. Textbooks are a supporting tool to facilitate the implementation, assessment and development of learning for students. Therefore, researchers designed teaching books according to standards outlined by the government. The method used at this stage is library research and individual work. The results obtained at this stage is the specification of history textbooks models, MORE which will be validated by a validator

At this develop stage,the researchers conducted the validity of the model history textbooks MORE assisted by three teachers from the State University of Surabaya. Three Surabaya State University lecturers, as validators who conductedmodel history textbook assessments MORE that had been developed by researchers. The results of the validator's assessment are as follows. 


\begin{tabular}{lc}
$\begin{array}{c}\text { Table 1. Quality of History Textbook Model MORE } \\
\text { Indicator of Development of } \\
\text { Historical Textbooks }\end{array}$ & $\begin{array}{c}\text { Average Validator } \\
\text { Value }\end{array}$ \\
\hline Content & 3.56 \\
\hline Presentation & 3.59 \\
\hline Languages & 3.94 \\
\hline Average & 3.69 \\
\hline
\end{tabular}

Based on the assessment from the validator, it is known that aspects of material content obtain an average of 3.56 , in the presentation aspect the average is 3.59 , and the language aspect obtains an average of 3.96. The three indicators have a final average value of 3.69. The following is an interpretation of the quality of history textbooks according to Riduwan (2012), as follows. The average value of the model textbook MORE has an average of 3.69. Thus the history textbook model MORE has a very good category for use in research. Development testing is done to determine student learning outcomes after using the model textbook MORE in learning history. The trial was conducted using the method pre experimental with design one group pretest posttest. The following are student learning outcomes using the model history textbook MORE.

Test normality pre-test is done to find out whether the data obtained is normally distributed or not, using the nomination test Shapiro Wilk. The following are the results of the normality test. Based on the output, it SPSS can be seen that the Sig. amounting to 0.067. Because Sig. (p)>0.05 which is $0.067>0.05$ so that the data is normally distributed. It can be drawn that the pre test data is normally distributed. Normality posttest was competence competencycarried out to find out whether the data obtained was normally distributed or not, using thenomination test Shapiro Wilk. The following are the results of the normality test. Based on the output, it SPSS can be seen that the Sig. amounting to 0.490 . Because Sig. (p) $>0.05$ which is $0.490>0.05$ so the data is normally distributed. It can be drawn that the post test data is normally distributed based on the normality test of Shapiro Wilk.

The homogeneity test is conducted to find out whether the data obtained is homogeneous or not, using the homogeneity test Levene. The following are the homogeneity test results. Based on output SPSS can be seen that the Sig. amounting to 0.174 . Because Sig. (p)> 0.05 which is $0.174>$ 0.05 indicating that the data group came from a population that has the same variant (homogeneous). It can be drawn that thedata values pre test and post test have the same variant (homogeneous).

Tabel 2. Result of Paried Sample T Test

\begin{tabular}{lcc}
\hline & T value & P value \\
\cline { 2 - 3 } Pretest and Posttest & $-8,797$ & 0.000
\end{tabular}

Based on output it SPSS can be seen that the Sig. amounting to 0,000 with Sig. (p) $<0.05$ which is $0,000<0.05$. Because Sig. (p) smaller than $\alpha 5 \%$, it can be concluded that there are differences in knowledge competencies in the data pre test and post test (there is a significant influence on the use of the model textbook MORE on student learning outcomes.

Reliability of the Textbook on the History of Republic of Indonesia Minister of Education and Culture Regulation Number 8 of 2016 states that textbooks or non-textbooks are a means of learning processes for teachers and students to improve basic knowledge for education. the book presented must be arranged attractively, easily understood, has a high level of neglect and fulfills positive values / norms that apply in society.The history textbook gets an overall average score of 
three expert experts of 3.58 with a very good category. On the feasibility of the content / material of history textbooks, the relevance aspect has an average score of 3.67 categorized very well, the adequacy / material adequacy aspect has a mean score of 3.42 categorized well.The accuracy aspect of the mean score of 3.83 is categorized very well and the proportionality of the material with the average score of 3 is categorized good, in the presentation of history textbooks, a the completeness specs of the average score of 3.89 were categorized very well. The suitability aspect of the presentation withlearning guidance student cetered has an average score of 3.5 categorized very well. The aspect of presentation with an average score of 3.67 categorized is very good. In the language of history textbooks, the language suitability aspect has a very good categorized score of 4 and the readability aspect with a mean score of 3.89 is very good. Thus it can be concluded that the history textbook has very good quality.

\section{CONCLUSION}

Based on the results of research conducted on the development of historical teaching materials using the model, MORE conclusions can be drawn. The quality of the history textbookmodel MORE has good quality based on the evaluation of the validator. Historical textbooks using themodel MORE can have a significant influence on historical learning.

\section{REFERENCES}

Ahmadi dan Amri. (2014). Pengembangan dan model pembelajaran tematik integratif. Jakarta: prestasi pustaka.

Carillo, L., Chis. L., \& Dwan R. (2015). Enhancing science teaching by doing. The Science Teacher, 60-64.

Creswell, J.W. (2015). Penelitian kualitatif \& desain riset memilih diantara lima pendekatan, Edisi 3. Yogyakarta: Pustaka Belajar.

Culsum, N. T. U., Helsy, I. F., \& Imelda. (2013). Kemampuan siswa menghubungkan tiga level representasi melalui model MORE (Model-Observe-Reflect-Explain). Prosiding Simposium Nasional Inovasi dan Pembelajaran Sains 2013 (SNIPS 2013). 159-163.

Daryanto dan Dwicahyono. (2014). Pengembangan perangkat pembelajaran (silabus, rpp, phb, bahan ajar). Yogyakarta: Gava Media.

Kemendikbud, (2016). Peraturan menteri pendidikan dan kebudayaan No. 8 tentang buku yang digunakan oleh satuan pendidikan. Jakarta: Kemendikbud.

Kosasih, E. (2014). Strategi belajar dan pembelajaran implementasi kurikulum 2013. Bandung: Yrama Widya.

Prastowo, A. (2013). Pengembangan bahan ajar tematik. Yogyakarta:Diva Press.

Riduwan. (2015). Metode dan teknik menyusun tesis. Bandung: Alfabeta.

Thiagarajan, S. D. S., and Semmel, M. I. (1974). Instructional development for training teachers of exceptional children a sourcebook. Bloomington Indiana: Indiana University.

Minh, T. H. N. (2011). Learning to communicate in a globalized world: To what extent do school texbooks facilitate the development of intercultural pragmatic competence?. RELC Journal. 42(1), 17-30. DOI: 10.1177/0033688210390265.

Bruhn, A. L. \& Hasselbering, T. S. (2013). Insreasing student access to contente area textbooks. Intervention in School and Clinic, 49(1), 30 -38. DOI: 10.1177/1053451213480030. 
Faas, D \& Ross, W. (2012). Identity, diversity and citizenship: a critical analysis of textbooks and curricula in Irish schools. International Sociology, 27(4), 574 -591. DOI: 10.1177/0268580911423057.

Howson, G. (2013). The development of mathematics textbooks: historical reflections from a personal perspective. ZDM Mathematics Education, 45, 647-658. DOI: 10.1007/s11858-0130511-9.

Gurung, R \& Landrum, R. E. (2012). Comparing student perceptions of textbooks: does liking influence learning? International Journal of Teaching and Learning in Higher Education, 24(2), 144-150. http://www.isetl.org/ijtlhe/.

Maher, A. (2004). Learning outcomes in higher education: implications for curriculum design and student learning. Journal of Hospitality, Leisure, Sport and Tourism Education. 3(2),. DOI:10.3794/johlste.32.78.

Micheal, N., Carter III, J, J., \& Varela, O. (2009). Active versus passive teaching styles: an empirical study of student learning outcomes. Human Resource Development Quarterly, 20(1), 397418. DOI: $10.1002 / \mathrm{hrdq}$.

Frye, R. (1999). Assessment, accountability, and student learning outcomes. Office of Survey Research. 430.https://cedar.wwu.edu/surveyresearch_docs/430.

Shephard, K. (2008). Higher education for sustainability: seeking affective learning outcomes. International Journal of Sustainability in Higher Education. 9(1), 87-98. DOI 10.1108/14676370810842201.

Trigwell, K \& Prosser, M. (1991). Improving the quality of student learning: the influence of learning context and student approaches to learning on learning outcomes. Higher Education, 22, 251-26.

Yang, D. C \& Sianturi, I. A. J. (2017). An analysis of singaporean versus indonesian textbooks based on trigonometry content. Eurasia Journal of Mathematics, Science and Technology Education, 13(7). DOI: 10.12973/eurasia.2017.00760a 